\title{
EFFECT OF CRUDE OIL EXTRACTS ON EARLY STAGES OF AFRICAN CATFISH HETEROBRANCHUS LONGIFILIS (VAL.) REARED UNDER CONTROLLED CONDITION
}

\author{
I. EWA-OBOHO AND O. AMU \\ (Received 27 March, 2009; Revision Accepted 4 December, 2009)
}

\begin{abstract}
Eggs and larvae of Heterobranchus longifilis were exposed to extracts of different concentrations of Nigerian Bonny light crude oil and Exxon Mobil Oso off-shore condensate during a comparative toxicity experiment carried out in the Institute of Oceanography Fish Farm, University of Calabar, Nigeria. Petroleum hydrocarbon was extracted from the two oils in separate 30litre glass aquaria and the eggs and young larvae were contaminated by exposing them to three concentrations of both oils, viz: $10^{1}$, $10^{3}, 10^{2} \mathrm{ppm}$ for approximately 10 days. Young eggs seemed to be more sensitive from 5 to 30 hours after fertilization. Extract from $10^{4} \mathrm{ppm}$ of Bonny Light Crude and Oso condensate caused $40 \%$ and $30 \%$ mortality respectively, after $100 \mathrm{~h}$. Embryos contaminated with Bonny Light crude extract did not recover on transfer to clean water. Delayed development was observed in the two-highest concentrations. Heterobranchus longifilis larvae were found to have a "mean critical time" of 4.2 days in the highest concentration of Oso condensate extract when larval integument was damaged. It is concluded that Bonny light crude could be a more dangerous pollutant to juvenile fish than the Oso condensate.
\end{abstract}

KEYWORDS: Heterobranchus longifilis, crude Oil extracts, Mortality, Bonny Light Crude, Exxon Mobil Oso Condensate.

\section{INTRODUCTION}

The marine environment adjacent to the Nigerian Gulf of Guinea is impregnated with a galaxy of oil rigs, flow stations and other petroleum based installations. This has resulted in oil entering the marine and adjoining estuarine waters from time to time. Oil drifted ashore and into the swamps could be harmful to littoral organisms as well as estuarine fisheries and fish stock (Kuhnold, 1982, Capuzzo, 1984, Anderson et al, 1986, Ewa-Oboho, 2006).

Many commercially important species have planktonic eggs and larvae which are abundant in the uppermost surface layers of oceanic water, and therefore exposed to the influence of petroleum components off-shores and inshore alike. The effect of floating films or undispersed crude oil on fish eggs and larvae has been investigated (Simpson, 1968, Capuzzo, 1984), Ewa-Oboho, 1994, 2006.
Water extracts of different concentrations of crude oil have been reported to show high toxicity on herring eggs when incubated under $10^{3}$ and $2.10^{4} \mathrm{ppm}$ with a mean survival time of 2.5 to 3.5 days (Kuhnhold, 1982). This high toxicity is mainly caused by low boiling components of petroleum hydrocarbons. The effect of oil condensate on juvenile fish and their early stages have not been seriously investigated even though petroleum associated paraffin hydrocarbons are magnificently exploited in the Gulf of Guinea coast off Akwa Ibom, South East Nigeria. Spills of oil condensate from Oso Exxon Mobil Oil rig readily enter the off-shore marine system and also drift into the adjoining estuaries. The present investigation compares the toxicity of oil condensate from Exxon-Mobil Oso rig and the Bonny Light Crude on the early egg and larval stages of the African catfish (Heterobranchus longifilis) which is highly priced in West African countries.

I. Ewa-Oboho, Department of Marine Biology, Institute of Oceanography, University of Calabar, Calabar. P.M. B. 1115 Cross River, Nigeria

O. Amu, Department of Marine Biology, Institute of Oceanography, University of Calabar, Calabar. P.M. B. 1115 Cross River, Nigeria 
MATERIALS AND METHODS

Eggs and young larvae of Heterobranchus longifilis, which have been fertilized and reared in the Institute of Oceanography (IOC) laboratory, were contaminated with dissolved and dispersed Bonny Light Crude Oil and Oso condensate. Experiments with dissolved petroleum hydrocarbons were carried out by extracting the oil and condensate in separate 30 L-glass aquaria to avoid direct application of oil films in the test containers. Different amounts of oil and condensate $\left(10^{4}, 10^{3}, 10^{2} \mathrm{ppm}\right)$ were separately poured into the water and left for two days. A calm water circulation in the containers was maintained by means of small pumps to ensure maximum saturation of soluble hydrocarbon compounds. Precaution was taken to reduced the level of evaporation of oil components by not exposing the experiment to direct sun light and strong wing. The oil extract was transferred into the test containers and renewed every two days. The amounts of Bonny light crude oil and Oso condensate used for preparing the extracts, is however not a criterion for the actual amount and types of dissolved hydrocarbons. Preliminary chemical analyses show that under the described test conditions the amount of hydrocarbons dissolved from $10^{4} \mathrm{ppm}$ of crude oil is in the range of 10ppm. Oil dispersions were obtained by stirring $10^{3} \mathrm{ppm}$ of Oso condensate for one minute at 10,000 revolutions per minute. Dilutions were then prepared at once. The experiments were started 50 hours later.

The effects of floating oil and dispersions were investigated by the addition of a relatively nontoxic dispersant corexit 7664. 10 and 100ppm of corexit were added when the oil was mixed with water representing 1 and 10 percent of the oil dispersed.

\section{RESULTS}

The mortality rates of $H$. longifilis eggs at different ages in the water extracts from Bonny Light Crude and Oso condensate, are represented in Figure 1. Fig. 1 shows that young eggs put into the oil extracts 5 to 30 hours after fertilization were more sensitive. On the other hand, after about 100 hours the extract from $10^{4}$ ppm of Bonny Light Crude had caused a $40 \%$ higher mortality than the control, unlike Oso condensate which caused a mortality of about $30 \%$ higher than the control.

The relationships between the mortality of $H$. longifilis eggs and duration of pollutant influence is represented in Table 1 which indicates that the mortality was lower when one series of eggs was kept in the extract throughout the test period.

Table 1: Relationships between mortality of H.longifilis eggs and duration of pollutant influence

\begin{tabular}{|c|c|c|c|}
\hline \multirow{2}{*}{$\begin{array}{l}\text { Amount of Bonny Light } \\
\text { Crude oil (ppm) }\end{array}$} & \multirow{2}{*}{$\begin{array}{l}\text { Test for 100 hours in oil } \\
\text { extract \% dead eggs }\end{array}$} & $\begin{array}{l}\text { In oil extract \% dead } \\
\text { eggs }\end{array}$ & $\begin{array}{l}\text { In clean water \% dead } \\
\text { eggs }\end{array}$ \\
\hline $10^{4}$ & 30 & 97 & 43 \\
\hline $10^{3}$ & 23 & 65 & 35 \\
\hline $10^{2}$ & 14 & 38 & 20 \\
\hline Control & 13 & - & 20 \\
\hline
\end{tabular}




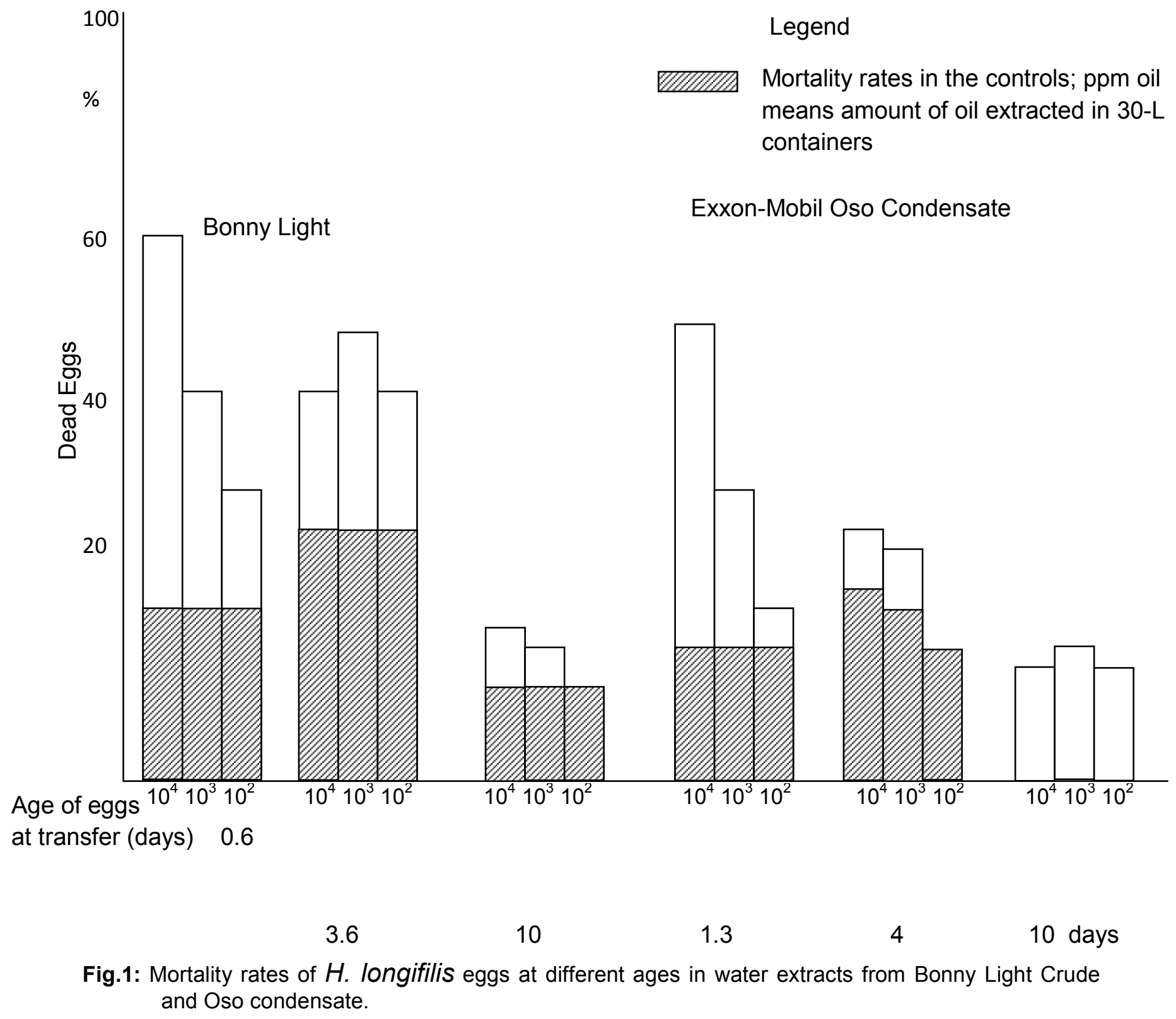

The hatching rates of H.longifilis eggs expressed as percentage of the control are shown in Fig. 2. After 5 to $30 \mathrm{~h}$ of fertilization, young eggs of $\mathrm{H}$. longifilis exposed to extracts of $10^{4}$ and $10^{3} \mathrm{ppm}$ were found to exhibit similar hatching rates $(<20 \%)$ of Bonny Light Crude as in the Oso condensate. However, higher hatching rates of $>80 \%$ were obtained in $10^{2} \mathrm{ppm}$ extracts of both pollutants after 10 days. The relationship

between larval sensitivity, pollutant concentration and exposure duration expressed as mean critical times, is shown in Table 2. $H$. longifilis larvae showed a mean critical time of 4.2 days when brought into the highest concentration of Oso condensate at the ages of 1 and 0.5 days when 10 days old. (Table 2). In the lowest concentration values were 14 days and $5-5$ days respectively. Resistances to oil extracts seem to 
decrease with advancing resorption of the yolk sac. Embryos contaminated with Bonny Light Crude extract did not recover although they were transferred to clean water after $48 \mathrm{~h}$.

The biological effects revealed more severe damage, because most of the larvae that hatched had deformed bodies or abnormal flexures of the tail which hindered normal swimming and most died within one day. The deformation was observed from gastrulation onward. A delay of development was observed in the two highest concentrations beginning from 3.5 to 4 days after putting the eggs into the test milieu. In some

Table 2: Mean Critical Time (days) of $H$. longifilis larval in dissolved petroleum hydrocarbons.

\begin{tabular}{|c|c|c|c|}
\hline $\begin{array}{l}\text { Age of } \\
\text { larvae at } \\
\text { transfer }\end{array}$ & \multicolumn{3}{|c|}{ Amount of Oil extracted (ppm) } \\
\hline & $10^{2} \mathrm{ppm}$ & $10^{3} \mathrm{ppm}$ & $10^{4} \mathrm{ppm}$ \\
\hline 1 & 14 & 8.4 & 4.0 \\
\hline 3 & 10 & 7.4 & 3.6 \\
\hline 5 & 8.1 & 5.8 & 2.4 \\
\hline 10 & 5.5 & 4.3 & 0.6 \\
\hline
\end{tabular}

cases, hatching was delayed or did not occur though the embryo looked normally developed.

The larvae on the other hand showed behavioural symptoms in oil extracts for example, increase in activity (especially in higher concentrations) was followed by a reduction of swimming activity, which finally stopped. The larvae then showed signs of narcosis, which gradually deepened until the critical point when no responses of larvae were obtained even by touching. These observations are similar to those reported by Wilson (1970).

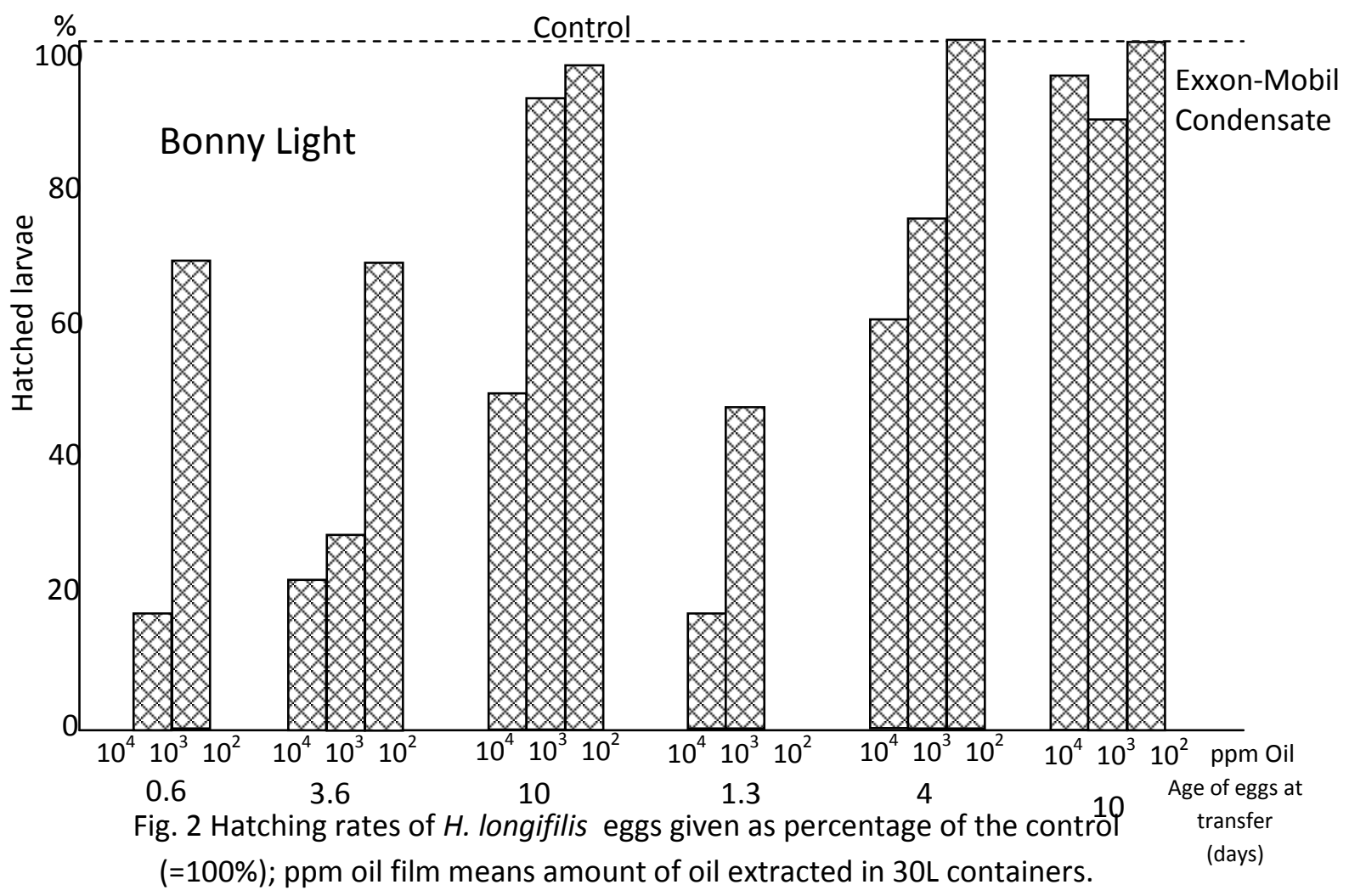


DISCUSSION

The acute toxicity of petroleum hydrocarbons to juvenile $H$. longifilis fish is assessed in the present studies by measurement of $\mathrm{LC}_{50}$ value $\ldots$ ie. the concentration of a hydrocarbon mixture that results in $50 \%$ mortality of the test fish during a designated exposure period. It is difficult to estimate the $50 \mathrm{LC}_{50}$ or $100 \mathrm{CL}_{50}$ of the eggs as mortality rate in the controls was $0-30 \%$ after $100 \mathrm{hrs}$ and highly dependent on the spawn quality. Young eggs put into the oil extracts 5 to $30 \mathrm{~h}$ after fertilization seemed to be most sensitive because of their delicate physiological stage which is usually very sensitive to pollutant.

Pure corexit solution of 10 and 100ppm concentrations were found to be non-toxic to larvae. Oil dispersions with and without corexit caused "mean critical times" of 3 to $6 \mathrm{~h}$ at $10^{3} \mathrm{ppm}$ of Oso condensate and 60 to $100 \mathrm{~h}$ at $20 \mathrm{ppm}$. After two days, the pure oil-water dispersion containing 100ppm of dispersant had kept or even slightly increased its toxicity at all dilution tested. The larval integument was damaged especially in higher concentrations. Typical row of blisters are formed on the primordial fins and tail fins. Larvae did not seem to avoid milky clouds of even higher concentration of dispersed oil, probably because their chemoreceptor were blocked very quickly at the first contact with oil component. It has been shown that toxic compounds are extracted from oil films in natural conditions in the sea during pollution, injuring larvae and young stages of floating eggs and yolk sac.

Several investigators have demonstrated that early embryonic and larval stages of fish are more sensitive to petroleum hydrocarbons than later larval stages (Ceas, 1974, Wells and Sprague, 1976, Donahue et al 1977, Linden, 1978, Cucci and Epifanio, 1979; Capuzzo and Lancaster, 1981, Ewa-oboho, 1988, Ewa-oboho and Abby-kalio, 2006, Asuquo et al, 2007). This is consistent with the results of the present study. The early embryonic stages were more sensitive than later embryonic and larval stages, possibly as a result of reduced membrane permeability to hydrocarbons (Sharp et al., 1979) or increased capability for detoxication (Binder and Stegeman, 1980) among later stages. The Bonny light crude possibly had higher concentrations of toxic aromatic components than Oso condensate which may probably be less dense and evaporates slowly than the Bonny light crude, hence, making the Bonny light crude more toxic than Oso.
To conclude, Bonny Light Crude seems to have a greater impact on early stags of $H$. longifilis. Dispersions from both types of oils can have a ten to hundred fold higher toxicity to both eggs and larvae, delaying growth or in most cases destroying the organisms.

\section{ACKNOWLEDGEMENTS}

We thank Exxon Mobil Producing Nigeria for the provision of Oil condensate from Oso platform. The Bonny light crude was obtained from Bonny Tank Farm of Shell Petroleum Development Corporation SPDC. The early stages of $H$. longifilis were made available by Mr. George Ekpo of the Institute of Oceanography Model Fish Farm, University of Calabar, Nigeria.

\section{REFERENCES}

Anderson, J. W., Kiesser, S. L. and Blaylock, J. W., 1986. Cumulative Effective Petroleum Hydrocarbon on Marine Fish during Constant Exposure. Rapp. P. V. Reun. Con. Int. Explor. Mer. 197:62-70.

Anderson J. w. and Stain, L. S. 1989. Effect of Crude Oil on Feeding Baheaviour of the Lobster Homarus americanus - Eviron. Pollut. 6:77-86.

Barnett, J. and Toews, D. 1978, Effects of Crude Oil and Dispersant Oil Sparse 43 on Respiration in Atlantic Salmon (Salmo Sala) J. Zool. 56:307-310.

Binder, R. L. and Stegeman, J. J., 1980. Induction of aryl hydrocarbon hydroxyl lase activity in embryos of an estuarine fish. Biochem. Pharmacol. 29: 949-951.

Capuzzo, J. M., 1984. The Effects of Petroleum Hydrocarbons on Lipid Metabolism and Energetics of Larval Development and Metamorphosis in Homarus americanus) Mar. Environ. Res. 14:201-228.

Ceas, M. P., 1974. Effects of 3-4 benzopyrene on fish egg development. Acta Embryological Experimentalis 3:267-272.

Capuzzo, J. M. and Lancaster, B. A. 1981. Physiological effects of Petroleum hydrocarbons in fish larvae: Hydrocarbon accumulation and interference with lipid metabolism. Page 477-59. In W.B. Vernberg, A Calabrese, F. P. Thurberg 
and F. J. Vernberg (eds.) Physiological Mechanisms of Marine Pollutant Toxicity. Academic Press, New York.

Cucci, T. L. and C. E. Ephifanio, 1979. Long-term effects of water-soluble fractions of Kuwait oil on the larval and juvenile development of the mud crab, Eurypanopeus depressus. Mar. Biol. 55: 215-220.

Donahue, W. H.; Wang, R. R.; Welch, M.; Nicol, J.A.C., 1977. Effects of water-soluble components of petroleum oils and aromatic hydrocarbons on barnacle larvae. Environ. Pollot. 13: 187-207.

Ewa-oboho, I., 1988. Effect of Simulated Crude Oil Spills on the Mangrove Swamps of the Upper Bonny-Estuary, An M. Phil Thesis, River State University of Science and Technology, Port Harcourt $289 \mathrm{pp}$.

Ewa-oboho, I. and Abby-Kalio, N. J., 1994. Effects of Simulated Oil Exposure on Two Intertidal Macrobenthos, Tympanotamus fuscata (L) and Uca tangeri in a tropical mangrove ecosystem. Ecotox, Environmental Safety. 28:243-248.

Ewa-oboho I., Asuquo F. E. and Oladimeji, S., 2006. Effects of Petroleum hydrocarbon pollution on Phytoplankton Primary Production and Community Respiration in the inner Shelf of the Gulf of Guinea. Trop. J. Environ. Res. 12:161-173.
Kuhnhold, W. W., 1982. Influence of Water Soluble Compounds of Crude Oils and their Fractions on the Ontogenetic Development of Herring Fry (Clupea herengus, L.) Ber. Det.Wiss. Kommn Mecres Forsch, 20 (2): 165-171.

Linden, O., 1978. Biological effects of oil on early development of the Baltic herring Clupea herengus membras. Mar. Biol. 45:273283.

Sharp, J. R.; Fucik, W. K. and Neff, J. M., 1979. Physiological bases of differential sensitivity of fish embryonic stages to oil pollution. Pages 85-108. In. W. B. Vernberg, A. Calabrese, F. P. Thurberg and F. J. Vernberg (eds.), Marine Pollution: Functional responses. Academic Press New York.

Simpson, C. A., 1968. The Torrey Canyon Disaster and Fisheries. Lab. Leafl. Minist. Agric. Fish Fd. (18): 43p.

Wilson K. W., 1970. Toxicity of Oil Spill Dispersants to Embryos and Larvae of some Marine Fish. Paper presented to FAO Technical Conference on Marine Pollution and its Effects on Living Resources and Fishing Rome, 9-13 Dec. 1970 FIR. MP/70?e-45:7p. 